\title{
Evaluation of pre induction scoring by clinical examination vs transvaginal sonography
}

\author{
Sonali Kaur Sharma*, Madhu Nagpal, CL Thukral
}

Department of Obstetrics and Gynaecology, SGRD IMSAR, Amritsar, Punjab, India

Received: 03 November 2016

Accepted: 30 November 2016

\section{*Correspondence:}

Dr. Sonali Kaur Sharma,

E-mail: drsonali.2246@yahoo.co.in

Copyright: ( ) the author(s), publisher and licensee Medip Academy. This is an open-access article distributed under the terms of the Creative Commons Attribution Non-Commercial License, which permits unrestricted non-commercial use, distribution, and reproduction in any medium, provided the original work is properly cited.

\section{ABSTRACT}

Background: The aim of the study was to find out pre-induction cervical length by TV Sonography, determine Bishops score and to co-relate the obstetric outcome with these two variables.

Methods: A study was done on 100 women with singleton pregnancies at 37-42 weeks of gestation, admitted for induction of labour in the Department of Obstetrics and Gynaecology at SGRDIMSR, Vallah, Amritsar, Punjab, India. All women underwent cervical assessment by both transvaginal ultrasound and Bishop Score and the outcome of labour induction was determined.

Results: Of the 100 women, 53 women had vaginal delivery and 47 landed into LSCS. Bishop score $<6$ and cervical length $>3 \mathrm{~cm}$ are cut off values of cervical unfavourablity. Successful induction was achieved among $87.5 \%$ and $78 \%$ women with favorable cervix according to Bishop Score and Cervical length respectively.Among the 92 and 50 women with unfavourable cervix according to Bishop score and cervical length, $48(52.17 \%)$ and 14 (28\%) had vaginal delivery respectively.

Conclusions: Hence, cervical length by transvaginal ultrasound is a better predictor for the success of induction of labour as compared with assessment by Bishop Score alone.

Keywords: Bishop score, Cervical length, Labour induction, Transvaginal ultrasound, Vaginal delivery

\section{INTRODUCTION}

Induction of labour, an obstetrical technique practiced since times immemorial is carried out in approximately $20 \%$ of pregnancies. ${ }^{1}$ The commonest indication for induction is prolonged pregnancy and several studies have shown that induction, compared to expectant management, is associated with a substantial reduction in perinatal mortality. ${ }^{2}$ However, approximately $20 \%$ of women having induction of labour end up having a Caesarean delivery. Successful induction of labour depends on length, position, softness and dilatation of cervix. The Bishop score, since its description in1964, remains the gold standard for assessing favourability for induction of labor. ${ }^{3}$ The classical digital examination is subjective and has intra and inter observer variability. Transvaginal ultrasound has been used successfully for measuring the length of cervix to predict duration of labour and obstetric outcome after labour induction. This method has been compared with the Bishop score achieving controversial results. ${ }^{4}$ On one hand it has been reported that the length of the uterine cervix, measured by transvaginal ultrasound, is a better predictor of the risk of Caesarean section after induction of labour for medical reasons than is the Bishop score. ${ }^{5}$ On the other hand it has been stated that transvaginal ultrasound does not improve on the prediction of cervical inducibility obtained by the Bishop score. $^{6}$

Recently measurement of cervical length by transvaginal ultrasonography for prediction of success of induction of labour is being used which is having more reproducibility ${ }^{7}$. It has been investigated as a way of predicting the likely outcome of induced labour as an 
alternative to clinical digital examination described by Anderson in 1991 and others. ${ }^{8-12}$ The elective induction can be done in various methods.

The use of intravenous oxytocin in induction of labour increased gradually since 1950 after the discovery of oxytocic effect of the posterior pituitary extract by Dale in
1906 and the synthesis of the Uterotonin by Du vigneud in $1950 .{ }^{13}$ The first systemic study of prostaglandin was by Kurzork and Liebin in 1930. At present prostaglandins are used in big way in induction of labour. ${ }^{14}$

Table 1: Bishop system of cervical scoring.

\begin{tabular}{|llllll|}
\hline Assessment score & Dilation $(\mathrm{cm})$ & Effacement $(\%)$ & Fetal station & Consistency & Position \\
\hline 0 & 0 & 0 to 30 & -3 & Firm & Posterior \\
\hline 1 & 1 to 2 & 40 to 50 & -2 & Medium & Mid \\
\hline 2 & 3 to 4 & 60 to 80 & $-1,0$ & Soft & Anterior \\
\hline 3 & 5 to 6 & 90 to 100 & $+1,+2,+3$ & - & - \\
\hline
\end{tabular}

Oxytocin and prostaglandins have been used for induction of labour in this study as these are considered safe and effective. There are many maternal and fetal indications for induction of labour, among them full term pregnancy is probably the commonest indication. ${ }^{14}$ In our study we have also taken past dates, pregnancy induced hypertension, PROM, oligohydramnios and latent labour as indications for induction. Though induction of labour has its own hazards like iatrogenic prematurity and associated perinatal mortality etc., but it has always been that the gains are on higher side in properly selected cases.

The present study was undertaken to evaluate the role of Bishop Score, cervical length by transvaginal ultrasound in predicting the outcome of labour induction at term gestation using misoprostol tablets.

The aim of the study was to find out pre-induction cervical length by TV Sonography, determine Bishops score and to co-relate the obstetric outcome with these two variables.

\section{METHODS}

The present study was done on 100 women with singleton pregnancies at 37-42 weeks of gestation, from October 2014 to June 2016, admitted for induction of labour in the Department of obstetrics and gynaecology at SGRDIMSR, Vallah, Amritsar. A detailed history was taken from all patients followed by general and systemic examinations. Transvaginal ultrasound assessment of cervical length was done followed by per vaginal examination for cervical assessment according to Bishop Score.

Bishop score $\leq 6$ and cervical length of $>3$ centimeters was taken as unfavourable cervix. In case of unfavourable cervix, induction was done using 25 micrograms Misoprostol tablet per vaginally, repeating the dose in 6 hourly until maximum of three doses. All cases followed with partographic representation. The primary outcome was taken as vaginal delivery with or without instrumental delivery. Cases landing in cesarean section were considered as failed inductions.

Table 2: Comparing the BS and CL by TVS in predicting primary outcome.

\begin{tabular}{|lllll|}
\hline \multicolumn{2}{|l|}{ Parameters } & \multicolumn{2}{l|}{$\begin{array}{l}\text { No. of } \\
\text { women }\end{array}$} & \multicolumn{2}{l|}{$\begin{array}{l}\text { Vaginal delivery } \\
\text { No of } \\
\text { women }\end{array}$} & Percentage \\
\hline \multirow{2}{*}{ BS } & $\leq 6$ & 92 & 48 & $52.17 \%$ \\
\cline { 2 - 5 } & $>6$ & 8 & 7 & $87.50 \%$ \\
\hline \multirow{2}{*}{ CL } & $>3 \mathrm{~cm}$ & 50 & 14 & $28.00 \%$ \\
\cline { 2 - 5 } & $\leq 3 \mathrm{~cm}$ & 50 & 39 & $78.00 \%$ \\
\hline
\end{tabular}

*BS - Bishop score, CL - Cervical length, TVS - Transvaginal ultrasound.

Table 3: Assessing the combined effect of BS and CL by TVS in predicting primary outcome.

\begin{tabular}{|c|c|c|c|c|c|c|}
\hline Total no. of women & BS & $\begin{array}{l}\text { No of } \\
\text { women }\end{array}$ & CL & $\begin{array}{l}\text { No of } \\
\text { women }\end{array}$ & $\begin{array}{l}\text { Vaginal delivery } \\
\text { within } \leq 24 \mathrm{hrs}\end{array}$ & $\%$ \\
\hline \multirow[t]{3}{*}{100} & \multirow[t]{2}{*}{$\mathrm{BS} \leq 6$} & \multirow[t]{2}{*}{92} & $\mathrm{CL}>3 \mathrm{~cm}$ & 44 & 15 & 34 \\
\hline & & & $\mathrm{CL} \leq 3 \mathrm{~cm}$ & 48 & 33 & 68 \\
\hline & $\mathrm{BS}>6$ & 8 & $\mathrm{CL}<3 \mathrm{~cm}$ & 7 & 6 & 85.7 \\
\hline
\end{tabular}


Table 4: Comparison of statistical analysis of similar studies.

\begin{tabular}{|lllll|}
\hline Study & VD $(\%)$ & CS $(\%)$ & Statistical analysis & $\begin{array}{l}\text { Better } \\
\text { predictor }\end{array}$ \\
\hline Ware et al & 69 & 31 & Logistic regression CL $(\mathrm{r} 2=0.28, \mathrm{p}<0.02)$ & $\mathrm{CL}$ \\
\hline Chandra et al & 80 & 20 & Logistic regression, BS $(\mathrm{p}<0.01)$ & $\mathrm{BS}$ \\
\hline Gabriel et al & 70.4 & 29.6 & ROC CL $(\mathrm{p}=0.006)$ & $\mathrm{CL}$ \\
\hline S H Yang et al & 75 & 25 & $\mathrm{X} 2$ test, CL $(\mathrm{p}=0.001), \mathrm{BS}(\mathrm{p}=0.045)$ & $\mathrm{CL}$ \\
\hline Gomes et al & 72.8 & 27.2 & $\mathrm{X} 2$ test, BS $(\mathrm{p}=0.000) \mathrm{CL}(\mathrm{p}=0.000)$ & $\mathrm{CL}, \mathrm{BS}$ \\
\hline Halil et al & 69.9 & 30.1 & Logistic regression CL $(\mathrm{p}=0.0101)$ & $\mathrm{CL}$ \\
\hline Daskalaiset al & 67.1 & 32.9 & AOC, CL $(\mathrm{p}<0.01)$ & $\mathrm{CL}$ \\
\hline Elghorori et al & 83.7 & 16.3 & $\mathrm{CL}($ Sen-62.1\%, Spe-100\%) & $\mathrm{CL}, \mathrm{BS}$ \\
\hline Strobel et al & 94 & 6 & Logistic regression, CL $(\mathrm{p}<0.0001), \mathrm{BS}(\mathrm{p}=0.001)$ & $\mathrm{CL}$ \\
\hline Anish et al & 76.8 & 23.2 & Logistic regression, CL $(\mathrm{p}=0.000)$ & $\mathrm{CL}$ \\
\hline P C Tanet al & 77.9 & 22 & Logistic regression, CL $(\mathrm{p}=0.005)$ & $\mathrm{CL}, \mathrm{BS}$ \\
\hline Gouri et al & 90 & 10 & $\mathrm{X} 2$ test, CL $(\mathrm{p}=0.00001)$ & $\mathrm{CL}$ \\
\hline Present study & 53 & 47 & $\mathrm{X} 2$ test, CL $(\mathrm{P}=0.000)$ & \\
\hline
\end{tabular}

VD - Vaginal delivery, CS - Cesarean section, AOC - Area of curve.

\section{RESULTS}

The indications for induction of labour were full term pregnancy $(66 \%)$, past dates $(7 \%)$, pregnancy induced hypertension (4\%), latent labour (9\%), PROM (7\%) and oligohydramnios $(7 \%)$. In present study, 53 women had successful induction i.e. vaginal delivery as favoured primary outcome. In 47 women cesarean section was done.

When Bishop Score was taken into consideration, among the 100 women, $\mathrm{BS} \leq 6$ was seen in 92 women. In them $48(52.17 \%)$ women had vaginal delivery. BS > 6 was seen in 8 women among them $7(87.5 \%)$ women had successful induction. When cervical length by TVS was taken into consideration, 50 women had cervical length $>3.0 \mathrm{~cm}$, in them $14(28 \%)$ women had vaginal delivery. Whereas 50 women had cervical length $\leq 3.0 \mathrm{~cm}$, in them $39(78 \%)$ women had successful induction.

Whereas when both the factors combined, 44 women who had both factors unfavourable i.e. BS $\leq 6$ and cervical length $>3.0 \mathrm{~cm}$, in them $15(34 \%)$ had vaginal delivery. 48 women had $\mathrm{BS} \leq 6$ and cervical length $\leq 3.0$ $\mathrm{cm}$, in them $33(68 \%)$ had successful induction. Only 1 woman had $\mathrm{BS}>6$ and $\mathrm{CL}>3.0 \mathrm{~cm}$ and successful induction was achieved in her case. Whereas 7 women had both factors favourable i.e. BS $>6$ and $\mathrm{CL}<3 \mathrm{~cm}$, in them $6(85.7 \%)$ had successful induction.

By using chi square test statistical analysis was done. According to the analysis, compared with Bishop Score $(\mathrm{P}=0.54)$, cervical length alone $(\mathrm{P}=0.000)$ and Bishop Score combined with cervical length $(\mathrm{P}=0.02)$ had shown significant relation with successful induction i.e. vaginal delivery within 24 hours.

\section{DISCUSSION}

The current method of evaluation of cervical condition before induction of labour is by Bishop score. But this score can differ from person to person due to more number of variables. This study primarily focused on detecting cervical change and likelihood of success of induction of labour by comparing the cervical length in centimeters measured by transvaginal ultrasound and Bishop Score in women with term gestation.

This study has compared the Bishop Score and cervical length by transvaginal ultrasound as in studies of Daskalakis et $\mathrm{al}^{15}$ and Anish et $\mathrm{al}^{16}$. In studies of Yang et $\mathrm{al}^{17}$ and Gomes et $\mathrm{al}^{18}$ also, primigravidae were more in number than multigravidae with $74 \%$ and $68.1 \%$ respectively. In our study we have taken women with gestational age of 37 to 42 weeks like in studies of Daskalakis et al, PC Tan et $\mathrm{al}^{19}$, Yang et al and Halil et $\mathrm{al}^{20}$. We have taken past dates, pregnancy induced hypertension and post term as the causes of induction as in studies of Yang et al, Gabriel et $\mathrm{al}^{21}$, Halil et al, Gomes et al and Anish et al study.

\section{CONCLUSION}

Cervical length by transvaginal ultrasonography proved to be better in predicting the success of induction of labour by having significant relation with vaginal delivery within 24 hours. Bishop score is also good in predicting the success of induction of labour but it is having comparatively less significant relation with vaginal delivery because of many variables and person to person variability in assessment. Cervical length by transvaginal ultrasonography can be used as an adjuvant 
to Bishop Score in assessment of cervix before induction of labour because of its higher predictive value and better tolerability. But cost of the equipment and experience in ultrasound are the drawbacks.

\section{Funding: No funding sources}

Conflict of interest: None declared

Ethical approval: Not required

\section{REFERENCES}

1. Pandis GK, Papageorghiou AT, Ramanathan VG, Thompson MO, Nicolaides KH. Preinduction sonographic measurement of cervical length in prediction of successful induction of labour. Ultrasound Obstet Gynaecol. 2001;18:623-8.

2. Cole RA, Howie PW, Magnaughton MC. Elective induction of labour -a randomized prospective trial. Lancet. 1975;1:767-70.

3. Bishop EH. Pelvic scoring for Elective induction. Obstet Gynaecol. 1964;24:269-71.

4. Bansiwal R, Rao R, Mishra N, Kapur V. International journal of reproduction, contraception. Obstet Gynaecol. 2013;2(4):611-5.

5. Gonen R, Degani S, Ron A. Prediction of successful induction of labour: Comparison of transvaginal ultrasonography and Bishop score. European journal of ultrasound. 1998;7:183-7.

6. Baacke KA, Edwards RK. Preinduction cervical assessment. Clinical Obstet Gynaecol. 2006;49(3):563-72.

7. Rane SM, Pandis GK, Guirgis RR, Higgins B, Nicolaides KH. Preinduction sonographic measurement of cervical length in the prolonged pregnancy: the effect of parity in the prediction of induction to delivery interval. J Ultrasound in Obstet Gynaecol. 2003;22:40-4.

8. Anderson HF. Transvaginal and transabdominal ultrasonography of the uterine cervix during pregnancy. American J Clin Ultrasound. 1991;19(2):77-83.

9. Bartha JL, Carmona RR, Fresno PM, Delgado RC. Bishop score and transvaginal ultrasound for preinduction cervical assessment: a randomized clinical trial. American $\mathrm{J}$ Ultrasound in Obstet Gynaecol. 2005;25:155-9.

10. Goldberg J, Newman RB, Rust PF. Interobserver reliability of digital and endovaginal ultrasonographic cervical length measurements. American J Obstet Gynaecol. 1997;177:853-8.

11. Park KH. Transvaginal ultrasonographic cervical measurement in predicting failed labour induction and cesarean delivery for failure to progress in nulliparous women. J Korean Med Sci. 2007;22:7227.

12. Ann SH, Luis SR, Andrew MK. Sonographic cervical assessment to predict the success of labour induction: a systematic review with meta analysis. American J Obstet Gynaecol. 2007:184-92.

13. Williams Obstetrics. 22nd ed. NewmYork: McGrawHill, Medical publishing division; 2005.p.535-46.

14. MacKenzie IZ. Induction of labour at the start of the new millennium. J Society for Reproduction and fertility. 2006;131:989-8.

15. Daskalakis G, Thomakos N, Hatziioannou L, Mesogitis S, Papantoniou N, Antasaklis A. Sonographic cervical length measurement before labour induction in term nulliparous women. J Fetal Diagn There. 2006;21:34-8.

16. Anish K, Vanita S, Rashmi B, Neelam A. Preinduction sonographic assessment of the cervix in the prediction of successful induction of labour in nulliparous women. Australian and New Zealand J Obstet Gynaecol. 2007;47:389-93.

17. Yang SH, Roch CR, Kim JH. Transvaginal ultrasonography for cervical assessment before induction of labour. American J Ultrasound Med. 2004;23:375-82.

18. Gomes F, Clara R, Ana PM, Elisa C, Filomena C, Nuno M. Transvaginal ultrasound assessment of the cervix and digital examination before labour induction. J Acta Med Port. 2006;19:109-14.

19. Tan PC, Vallikkannu N, Suguna S, Quek KF, Hassan J. Transvaginal sonographic measurement of cervical length vs. Bishop score in labour induction at term: tolerability and prediction of cesarean delivery. J Ultrasound Obset Gynaecol. 2007;29:568-73.

20. Halil A, Gokhan Y, Altan C, Yavuz C. Measurement of the cervical length in the prediction of successful induction of labor. J Perinatology. 2006;14:159-64.

21. Gabriel R, Darnaud T, Chalot F, Gonzalez N, Leymarie F, Quereux C. Transvaginal sonography of the uterine cervix to labour induction. J Ultrasound Obstet Gynaecol. 2002;19:254-7.

Cite this article as: Sharma SK, Nagpal M, Thukral CL. Evaluation of pre induction scoring by clinical examination vs transvaginal sonography. Int J Reprod Contracept Obstet Gynecol 2017;6:228-31. 